\title{
THE DILEMMA OF SUSTAINABILITY IN THE DEVELOPMENT PROJECTS OF RURAL COMMUNITIES IN EGYPT - THE CASE OF NEW GOURNA
}

\author{
K. GALAL AHMED ${ }^{1} \&$ L. EL-GIZAWY ${ }^{2}$ \\ ${ }^{1}$ Department of Architectural Engineering, United Arab Emirates University, UAE. \\ ${ }^{2}$ Department of Architectural Engineering, Mansoura University, Egypt.
}

\begin{abstract}
Gourna, a vernacular village in Upper Egypt, was built over a Pharonic heritage site. During the 1940s, and in order to protect the monuments from theft, the Egyptian government commissioned the renowned Egyptian architect Hassan Fathy to design a new settlement for the Gournii. Despite the great effort exerted by Fathy to design The New Gourna in an environmentally and socially responsive manner, the project had considerably failed as most of the residents refused to move to the new village. Recently, the government repeated the attempt but this time the second version of the New Gourna came significantly different. In order to force them to move, the government demolished most of the houses of the residents of Gourna and left only a few houses to be re-used as museums for the vernacular architecture of the village. The main objective of the paper is to investigate if the second version of the New Gourna is going to overcome the sustainability problems associated with Fathy's New Gourna and if it is going to deal successfully with the sustainable vernacular architecture of the region. In order to undertake this investigation the paper first reviews the vernacular architecture of Gourna and then discusses both Fathy's approach and the recent New Gourna village's approach from the sustainability point of view. It has been found that, no matter how the good intentions were, both attempts to build New Gourna reveal how the top-down official processes ended up with either a superficial mimicry to the authentic vernacular and traditional architecture of the region, or a totally imposed alien built environment. Thus, from a sustainability perspective, it is expected that the recent project is going to end up in failure as its predecessor.
\end{abstract} Keywords: Egypt, Gourna, Hassan Fathy, Taref, sustainability, vernacular.

\section{INTRODUCTION}

In describing 'vernacular' as a term, Heath [1] maintains that when representative numbers of people within a region embrace aspects of a unique building response in a collective and consistent manner, they produce something that is 'vernacular', not idiosyncratic. From this perspective, Heath adds that vernacular architecture represents a localized response to broad cultural systems, historical events, and environmentally determined regional forces. Therefore, the study of vernacular environments inevitably acknowledges the range of forces acting on a particular society that prompts regional building patterns, spatial adjustments, and meaning. Among these forces are climatic, cultural, social, racial, historical, political, economic, and religious factors [1].

Analyzing the effect of these forces on shaping vernacular architecture has resulted in a coherent link between vernacular architecture and sustainability. In Egypt, as in other Middle Eastern countries, there are many examples that illustrate this link through the sustainability features of vernacular architecture and urbanism in local communities. It has been claimed that the vernacular architecture in the Middle East presents a rich heritage of knowledge on dealing with the hot arid climate of the region. For example, indigenous techniques of creating naturally cool internal spaces date back to a period when no sophisticated technical inventions were at hand to affront nature's rigor or to upset the balance of nature. These vernacular techniques were the result of man's experience of understanding and harnessing the extremes of nature to survive and thus they were inherently sustainable [2]. An example for such vernacular communities in Egypt is the Gourna village, a small village in Upper Egypt near to Luxor. Gourna was incrementally built by its residents 
about 100 meters to the east of the Temple of Seti I and spread over 8 kilometers by the west bank of the Nile River (Fig. 1) [3].

The distinguished vernacular architecture and urbanism of Gourna have been threatened for decades based on the belief that the Gournii, for generations, had made their livelihood by tunneling into the tombs, plundering the contents, and selling the artifacts on the black market. It has been claimed that they built their houses in front of the tunnels to accord a certain degree of security to their operations [5]. Determined to stop the tomb robbing, the Egyptian Department of Antiquities engaged Fathy in 1946 to design and construct a new village, known as The New Gourna or in Arabic (Gourna El-Gedida) (Fig. 1), as a potentially cost effective solution to the problem of relocating the entire entrenched community of the envisaged entrepreneurial excavators [6]. Recently, on the same background and after about half a century of the failure of Fathy's project, the Egyptian government repeated the attempt but this time forced the residents to evacuate their homes and move to a new site. The government then immediately demolished most of these homes and thus the vernacular architecture and urbanism of Gourna suddenly became history.

The main objective of the research is twofold. First is to investigate the sustainability-related problems associated with the Fathy's New Gourna experience and second is to discuss if the second version of New Gourna, known also as New Al Taref Village (Fig. 1), is going to overcome these problems and thus end up with a sustainable community for the people of Gourna. In order to undertake this investigation the research first reviewed a background about vernacular architecture of 'old' Gourna and then discussed both Fathy's approach and the recent approach adopted in the new development focusing on the generic environmental, socio-cultural, and economic features of sustainability. The research ends up with a comparison between the two versions of the New Gourna to help realize the research objectives.

\section{VERNACULAR COMMUNITY OF GOURNA: BACKGROUND}

Gourna was a thriving community of five hamlets built along the hills in West Luxor, on the ancient cemetery of Thebes. Much of Gourna was originally built on the hillside. Until the early nineteenth century the community included at least parts of the Temple of Seti I. Edward William Lane relates

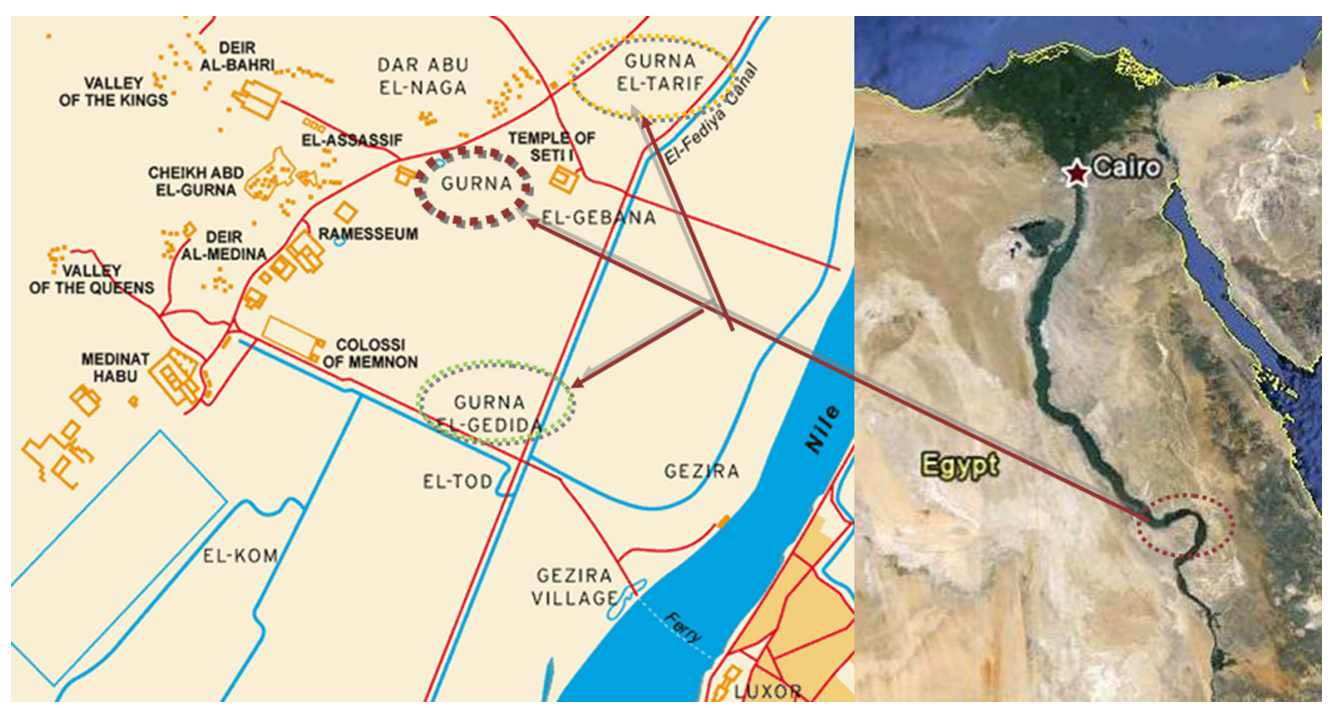

Figure 1: The location of Gourna village near to the Valley of the Kings. Source: [4] and Google Earth. 
in 1825 that the village was abandoned and not a single inhabitant lived there. Isabella Frances Romer suggests that the resettling started in the late 1840s [7]. The number of families kept increasing since then and reached to about 119 in 1948 and over 3200 in 2006 [8]. Gourna consisted mainly of seven neighbouring residential headquarters named $\mathrm{Al}$ Attaiat, $\mathrm{Al}$ Ghabat, $\mathrm{Al}$ Hasasnah, Al Horobat, Gourna, Gornet Morai, and Ramseuim. Before its demolition in 2006, the Gourna village had no infrastructure except electricity. Considering them a squatter community, the Egyptian government refused to provide drinking water supplies or sanitary drainage systems for Gournii. As a result, the improper drainage of sewage water from Gourna houses badly affected some of the Pharaonic tombs [9].

\subsection{Features of vernacular sustainability in Gourna}

In Gourna, many features of environmental, socio-cultural, and economic sustainability can be observed on different scales. On the urban scale, the houses were built juxtaposed to each other forming compact residential clusters separated by narrow streets (Fig. 2). The irregular urban pattern of the village came as a direct result of the residents' decisions influenced by the community values and traditions without intervention from outside authorities and thus, helped in creating social cohesion and mutual interdependence among the members of the local community. With the resultant shaded streets and the groupings of relatives in the same residential cluster in a hierarchical spatial order, this crooked layout of Gourna was a manifestation of meaningful community decisions that, no doubt, nurtured the social and environmental sustainability of its members.

Additionally, the built environment was a mixed-use one where shops and workshops occupied some of the ground floors of the Gournii houses, especially in those that abut main streets. As a direct reflection of the community social traditions, the open spaces in front of houses were practically utilized as extension zones for the social and cultural activities taking place inside the houses. Therefore, these spaces used to be scenes for different social and economic activities helping realizing social and economic sustainability of the local community. Among these activities were sitting areas for housewives, play areas for children, cooking and domestic uses, and rearing poultry and other farm animals (Fig. 3). Some of these activities required demarcation and appropriation of the open areas in front of houses shaping livable and vivid urban spaces within the residential context. As a result of this mixed-used nature of the village and the compactness of its urban form, people of Gourna rarely relied on mechanical vehicles; instead they either walked or used donkeys as a means of transportation among different community activities and facilities.
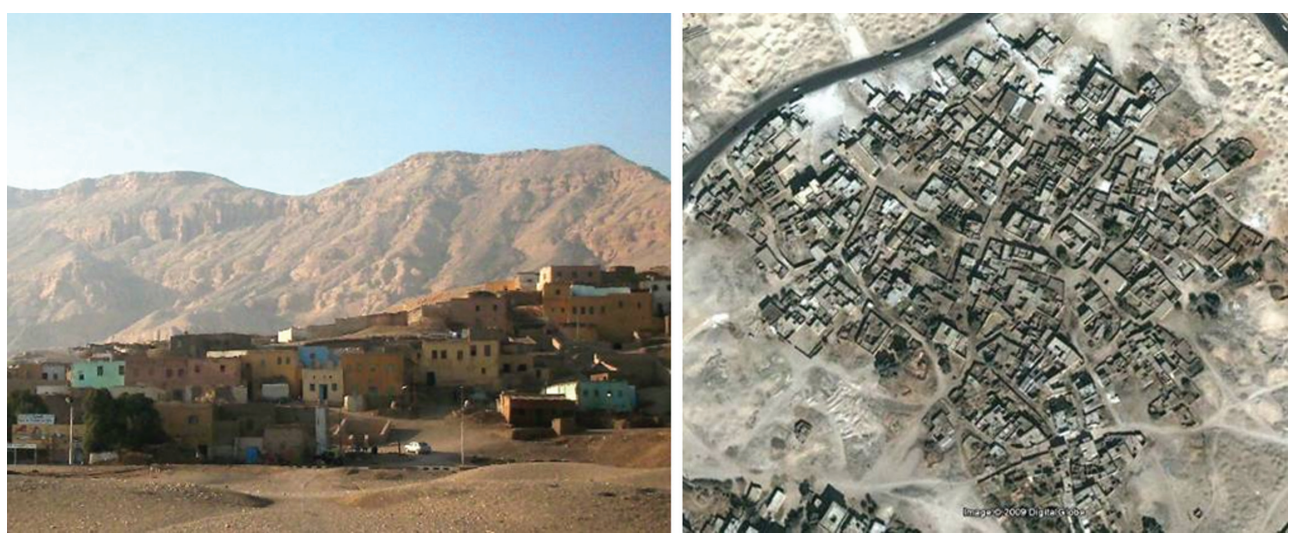

Figure 2: The irregular urban form of Gourna. Source: Authors and Google Earth. 

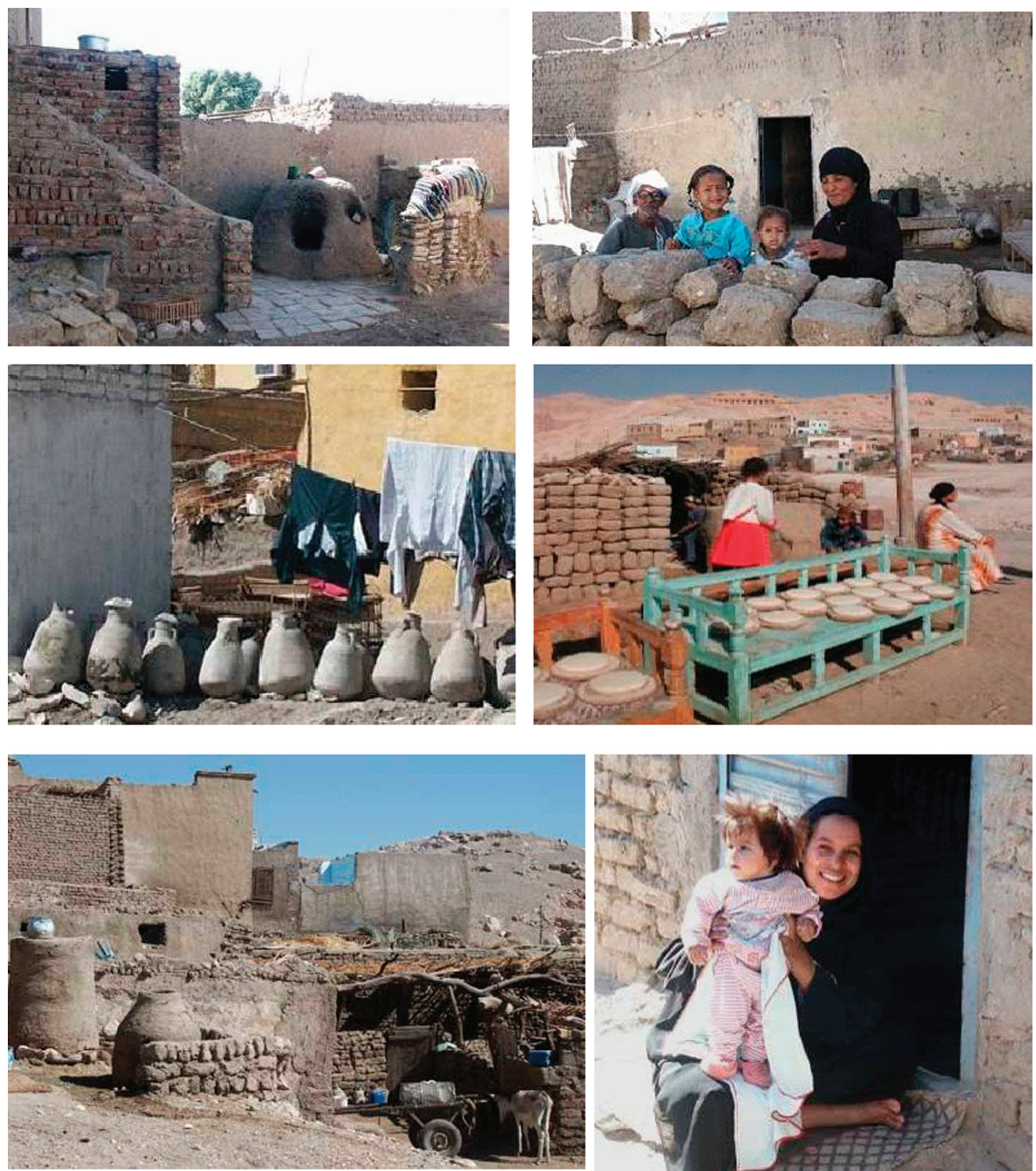

Figure 3: Demarcation and appropriation of open spaces juxtaposed to the houses in Gourna [10, 11].

The main source of income for many of the residents in Gourna used to come from alabaster related handicrafts. The residents actively carved various objects from slabs of alabaster to sell to tourists visiting the surrounding tombs and temples (Fig. 4). Also, some of them rented rooms in their houses and offered food to tourists who liked to experience the local life of the Gournii and stay for a longer period in the area [5]. By doing so, Gournii were able to generate incomes sustaining their livelihood without relying on governmental assistance or support. The skills gained by the residents were transferred from one generation to another creating a sustainable job security for the people of Gourna. 


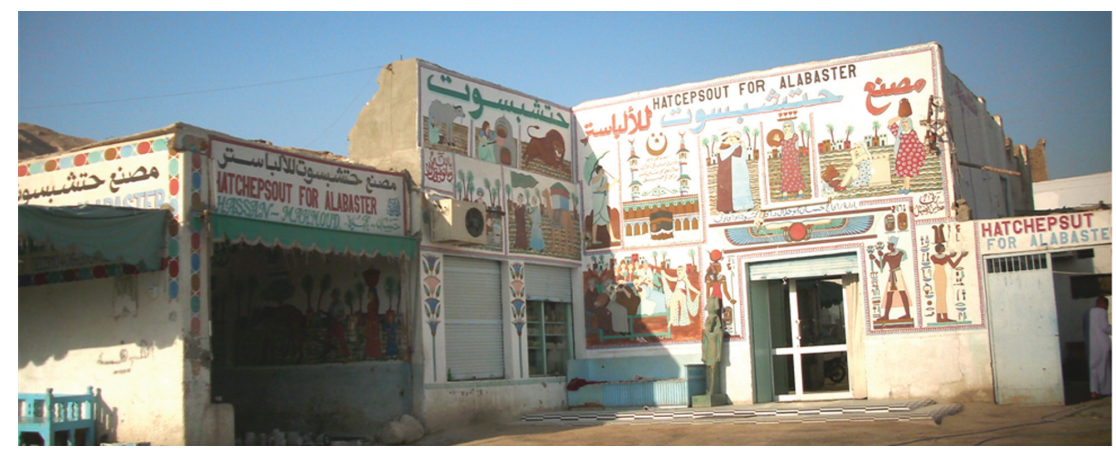

Figure 4: Alabaster shops in Gourna. Source: Authors.

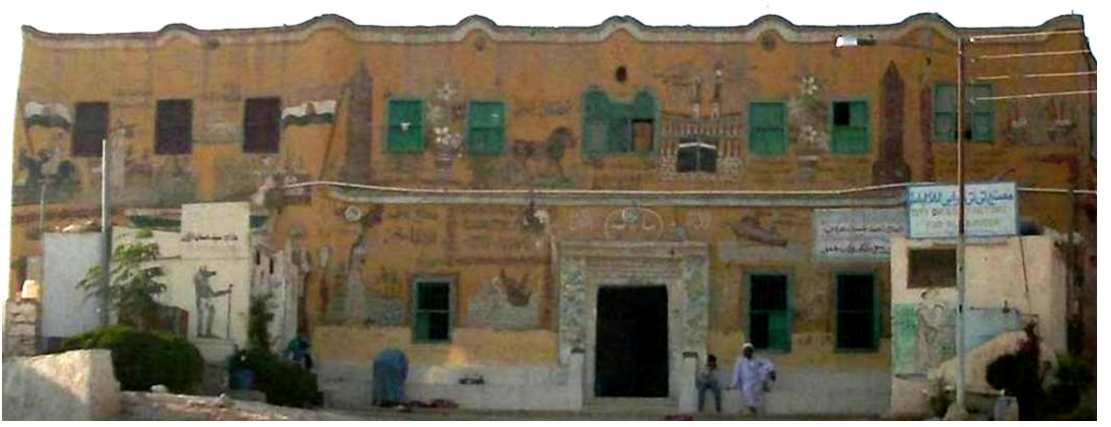

Figure 5: Vernacular ornaments on the exterior walls of a house in Gourna. Source: Authors.

The vernacular architecture features of the Gournii house demonstrated other influential sustainability dimensions. On the social and economic dimensions, the houses were built by the residents themselves using local and recyclable building materials including mud bricks and palm wood following simple appropriate construction methods. Fathy [12] stated that when he saw a little house in Gornet Morai, one of the names of residential quarters in Gourna, he realized a straightforward adaptation of the materials to the purposes of the peasant's life where each detail was built because the peasant wanted it and where he wanted it, in the most convenient shape and size. Fathy [12] added that the house had the quiet self-sufficiency of any artifact produced by a competent professional. This particular kind of plasticity and informality cannot be reproduced from a drawing board. It is conceived as it is built, like a piece of modeling in clay, and flat drawing has no part in the process. Therefore, Fathy believed that such a house must be built by the owner, for every irregularity and curve is a reflection of his personality.

The height of Gourna houses generally ranged from one to two stories. In Gourna, fathers used to build upper floors for their newly married sons forming extended families sharing the same house. On the other hand, the walls of the Gourna houses and shops were like an open exhibition for vernacular expression of community folk arts. The residents used to ornament the facades of their houses with drawings and writings to celebrate and commemorate their different social and cultural occasions such as performing the pilgrimage to Mecca or with the aim to attract tourists to their shops [13]. These drawings were inspired by vernacular arts, religious features, rural scenes, and Pharaonic legends (Figs 4 and 5). 
Residents conventionally paid considerable attention to the formation of the main facades of their houses where easily identifiable common architectural motives were used to form the entrances and skylines and give them distinguished vernacular character. Colors, especially blue, yellow, and brown, the representatives of the colors of the sky, desert, and earth, also played a key role in shaping this sense of 'diversity within unity' in the urban fabric of Gourna village (Figs 5 and 6).

The inner courtyard formed an essential spatial pattern around which most of the rooms are grouped, thus creating a social hub for the interaction among the households. A staircase leading to the upper floors was usually found on the inner periphery of this court (Fig. 7).

On the environmental level, besides the important role played by thick mud walls and partially or entirely earth sheltered spaces that were carved into the hills (usually used as stores) in alleviating the severe heat especially in summer, the inner court also was the source for natural lighting and natural cross-ventilation. In addition, biomass fuel was the chief source of energy used to operate stoves mainly located in the courtyard outside the house. Big burnt clay jars kept under the main staircase in the inner courtyard utilizing evaporative cooling was the main source for chilled drinking water desperately desired in such hot climate (Fig. 7).

In conclusion, the features of the Gournii vernacular community mentioned earlier are credible reflections of environmental, social, cultural, and economic sustainability through collective and

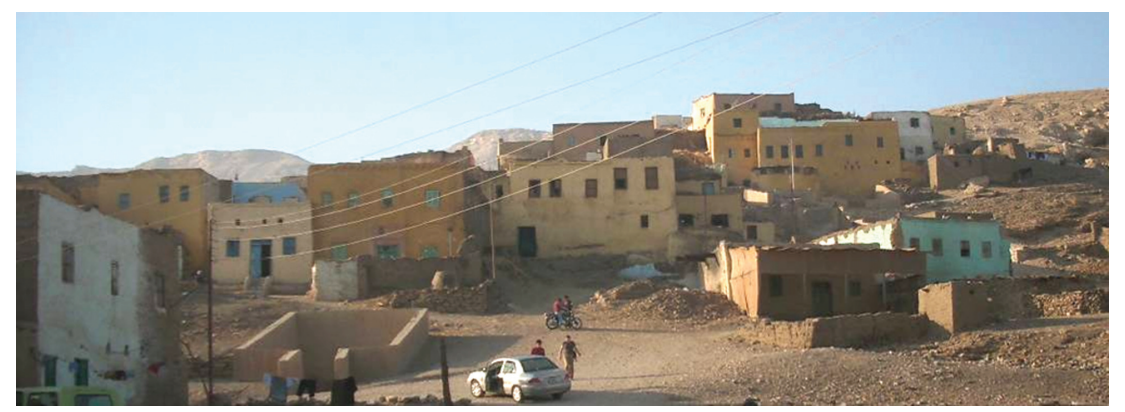

Figure 6: Using vernacular colors and architectural vocabularies in the walls, entrances, and skylines of the houses of Gourna. Source: Authors.
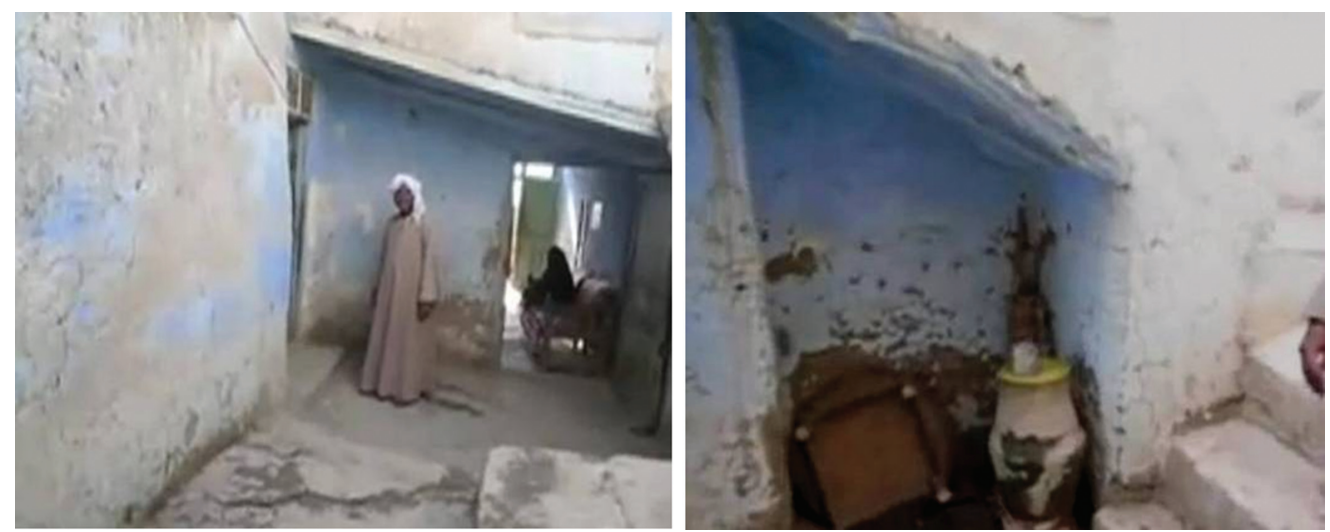

Figure 7: Inner courtyard in a house in Gourna, a social hub and a source for natural lighting and ventilation. Source: www.youtube.com. 
individual decision-making processes that came from within the Gourna local community itself and were not imposed on its members by outside local or central authorities.

\section{HASSAN FATHY'S NEW GOURNA}

New Gourna or Gourna El-Gedida village designed by the renowned Egyptian architect Hassan Fathy was partially built between 1945 and 1948, lying roughly midway between the Colossi of Memnon and el-Gezira on the Nile (Fig. 1) [7]. The 50-acre site allocated for the new village was intentionally chosen to be suitably far enough away from the tombs in a section of low lying agricultural land along the Nile, close to the main road and railway line [14]. Originally planned for a population of 900 families or 7000 Gournii [15], the completed project had only a population of approximately 130 families (in 1985) and covered only one-fifth of the original site [5].

\subsection{Urban and architectural development of Fathy's New Gourna}

The main objectives of Fathy's design, as he himself described, were to make the people of Gourna live in a harmonious social structure, free from abject poverty, disease, and illiteracy, devoted to the pursuit of folk art, and framed by an appropriate and relevant architectural setting [5]. Before embarking on the design of the new village, Fathy studied the living patterns of the Gournii in as much detail as possible given the prerequisites of family privacy and the obstructive reluctance of the Gournii to co-operate in their relocation. He found the village to be generally divided into five tribes within four distinct zones on the hillside and specifically separated into family groupings (badanas) within each tribe [15]. Fathy respected this four-part division in his layout design of the new village using the main streets as separators among the four quarters of the village; each of the main tribal groups of old Gourna was to be housed in one of these quarters (Fig. 8).

In order to realize his goals, Fathy planned the housing in irregular allotments (Fig. 8). In his view, these allotments would force variation in house plans while shaping a network of angular streets that turn on themselves to create broken vistas. He envisaged that much of the lives of households are to be played out in these small, quiet streets that serve as extensions to the home as workplaces and as play areas for children [5].

The main streets, at least 10 meters wide, separating the quarters were intended as main trafficroutes connecting all the public buildings and meeting in the main square. The width of these streets

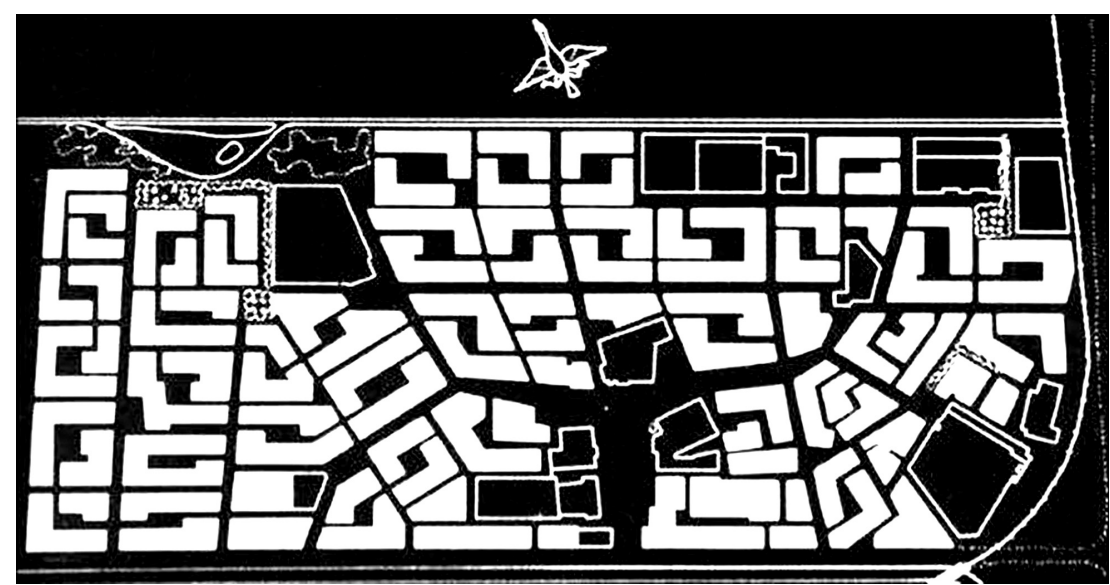

Figure 8: New Gourna original master plan, 1945 [5]. 
was meant to ensure good ventilation and isolation of the blocks of houses as well as to facilitate movement and to mark off the quarters. By contrast, the streets giving access to the semi-private squares were no more than 6 meters wide to provide shade and a feeling of intimacy. They also included many corners and bends so as to discourage strangers from using them as thoroughfares [15]. Steele [16] mentioned that in his designs for the public buildings and the houses of the New Gourna, Fathy was inspired by the triple principles of the spatial and environmental systems derived from the buildings in Old Cairo, the logic and economy of using mud brick and knowledge of the Nubian techniques of building. The village design began with the smallest unit in the hierarchy of open space, which is the multi-purpose courtyard incorporated into each house (Fig. 9).

Fathy built his design around an ascending scale of space that begins with the private courtyard, leading to the semi-public neighbourhood street, to the larger avenue, then the village square, and finally the open fields of the Nile Valley. On the other hand, the main route to the village interior widens to create a public square around which many of the community functions were to take place including prayer, shopping, and entertainment housed by the mosque, khan, and theatre, respectively. Informal socializing occurs in the streets or under the Byzantine domes that cover the village water wells (Figs 9 and 10) [5].
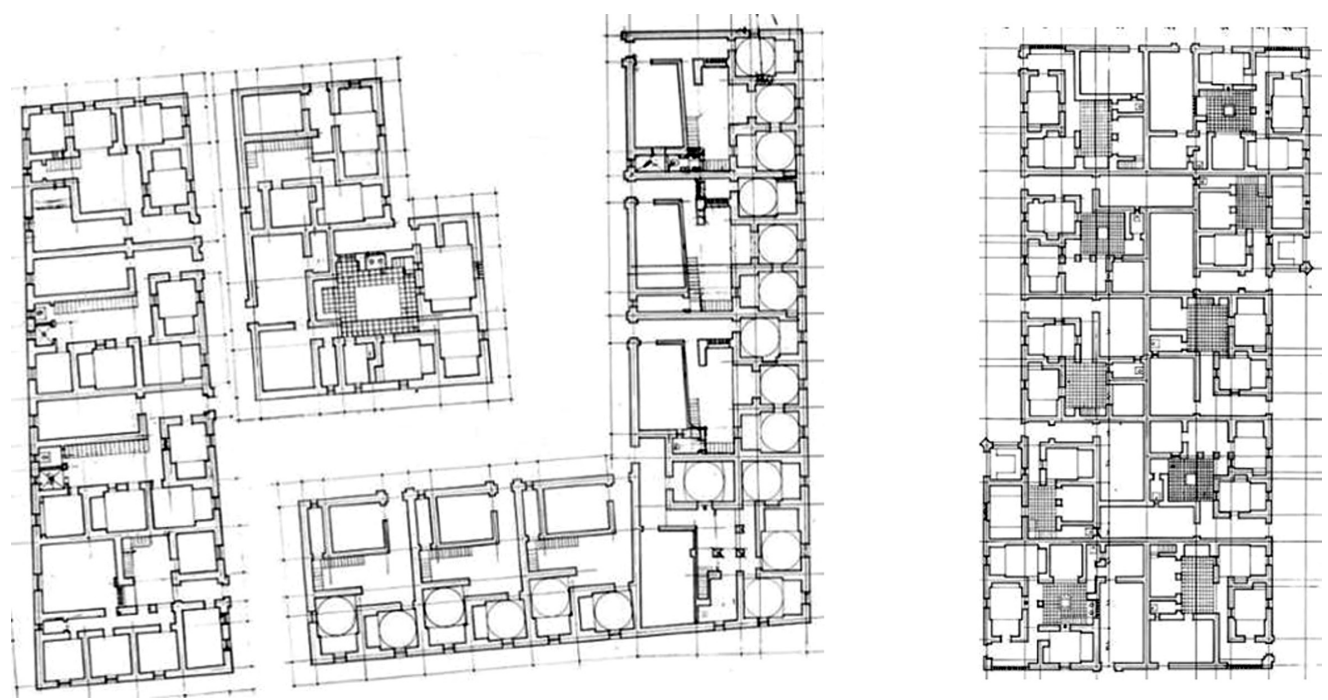

Figure 9: Neighborhood 4 and housing pattern including the multi-purpose courtyard [17].
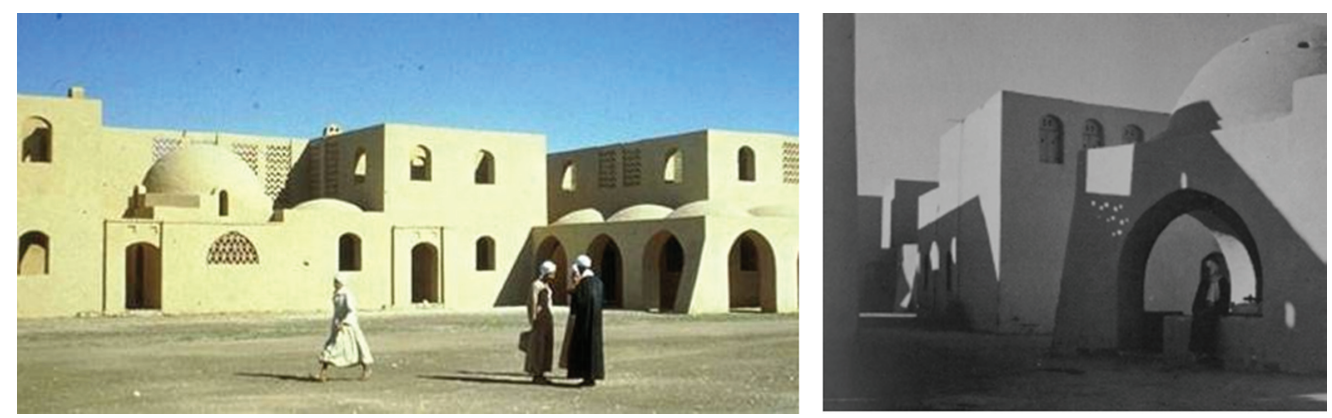

Figure 10: Hierarchy of open space in New Gourna village [12]. 
In New Gourna, Fathy stood against the bureaucratic approach to mass housing and the repetition of prototypes in ever-shifting combinations. Rather than subscribing to the current conventional idea of using a limited number of unit types, Fathy took the unprecedented approach of seeking to satisfy the individual needs of each family in the design (Fig. 11) [6]. Fathy argued in his book Architecture for the Poor that the architecture of the house emerges from the dream; this is why in villages built by their inhabitants we will find no two houses identical. This variety grew naturally as men designed and built their many thousands of dwellings throughout the millennia [12].

Fathy stated that in Gourna by compelling himself to fit the houses that varied in size according to the area of the original houses they were replacing into a variety of irregular plots and by being ready to vary the plan of each to suit the people who would live in it, he made sure that he should think carefully about the design of each one so as to avoid the trap of adding variety without purpose [15]. Fathy [12] clarified that in Gourna he had to huddle the buildings together because the site was small, and he had to give each house its cattle shed and its storage space inside the restricted area allotted to it. For this reason, Fathy added, all the houses had to be two-storied ones. On the ground floor of the house were the guestroom and the cattle sheds. Upstairs were the bedrooms and the fuel storage bin. The household services including cooking, washing, and latrines were grouped around the central courtyard that had a loggia where the family could eat (Fig. 12).
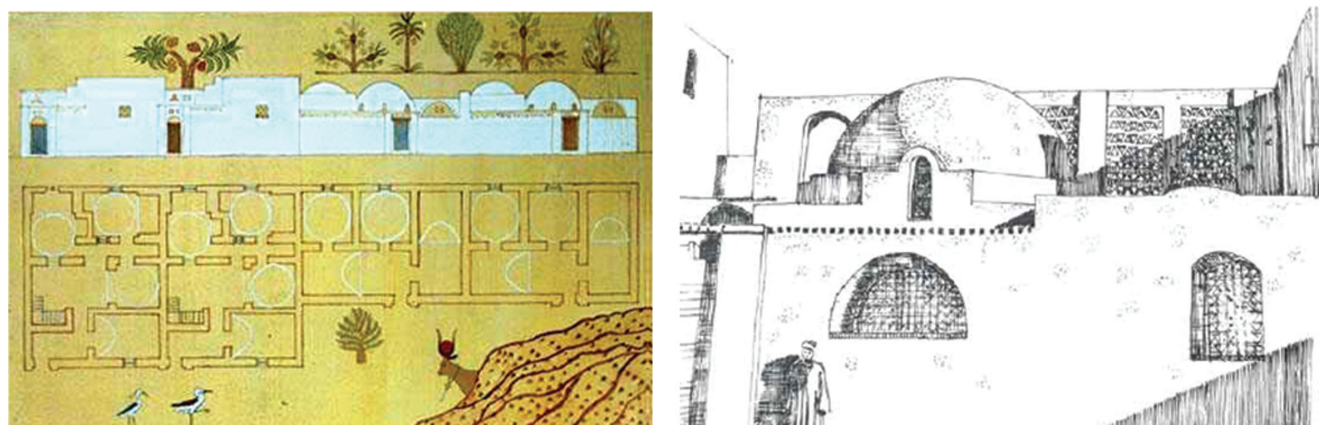

Figure 11: Design for a house in New Gourna [18].
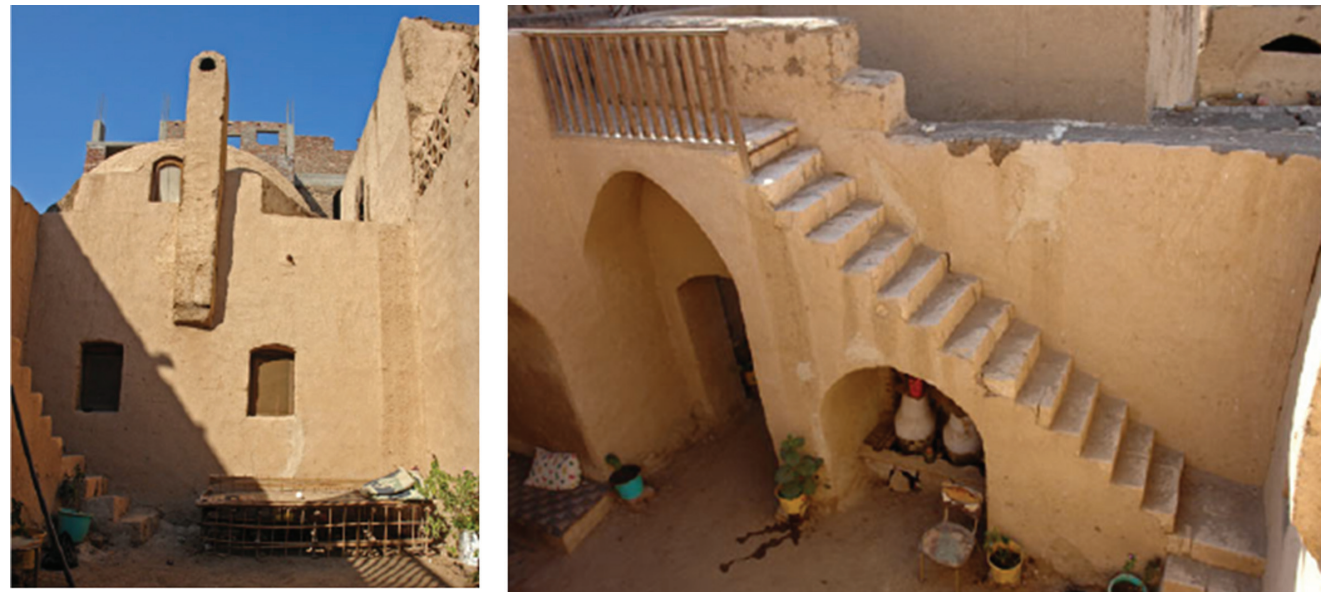

Figure 12: The inner courtyard in a house in New Gourna [12]. 
In his designs of New Gourna houses, Fathy [12] was inspired by the historical Arab house pattern where a square, domed room with vaulted alcoves off it reproduces the $k a^{\prime} a$ layout with its high central hall, clear of furniture, perhaps with a small fountain in the middle, and the iwans leading off it, each with its built-in seats. The central hall, the dorka' $a$, derives from an open courtyard, and the whole plan is reminiscent of that of an old Iraqi house or the earlier houses of Fostat in Egypt, with a central courtyard and the iwans at the sides. Fathy mentioned that he had used this basic pattern in his pre-Gourna houses and even in the village schools for arranging the classrooms (Fig. 13).

The traditional mushrabiya is another design item inspired from old Cairo that was employed in Fathy's design for fenestrations in both houses and public buildings. Socially, Fathy [12] mentioned that behind these mushrabiya windows the ladies of the house may sit and comfortably watch the street, in perfect seclusion without the need to peek out from behind curtains or to cross over the room to see out. Environmentally, Fathy claimed that the use of mushrabiya with the wind catch will free the designer from the need to orientate the house for the wind, and could consider simply the solar orientation. In fact, even this would be in some degree subservient to the exigencies of the plan, for if every building were arranged in the same way the plan would become monotonous.

Unfortunately, the year 1948 witnessed a dramatic end to Fathy's experience of New Gourna where the pressure that had been building from seemingly endless problems and setbacks finally reached a breaking point. Cracks began to appear in public buildings and houses ruining many of them. Many of the social services, such as the dispenser, women's social center, and the hammam (public bath), were neither provided nor facilitated, nor was all the proposed housing constructed (Fig. 14).

Several of the community buildings such as the crafts exhibition hall, the village hall, and the khan (market) were built but have never supported their intended functions and are now used as housing or workshop space [5]. Ultimately, the village was abandoned in its state of partial disrepair (Fig. 15) [14]. All what remains today of the original New Gourna is the mosque, market, and a couple of houses. Most other houses in the village today are of newer origin.
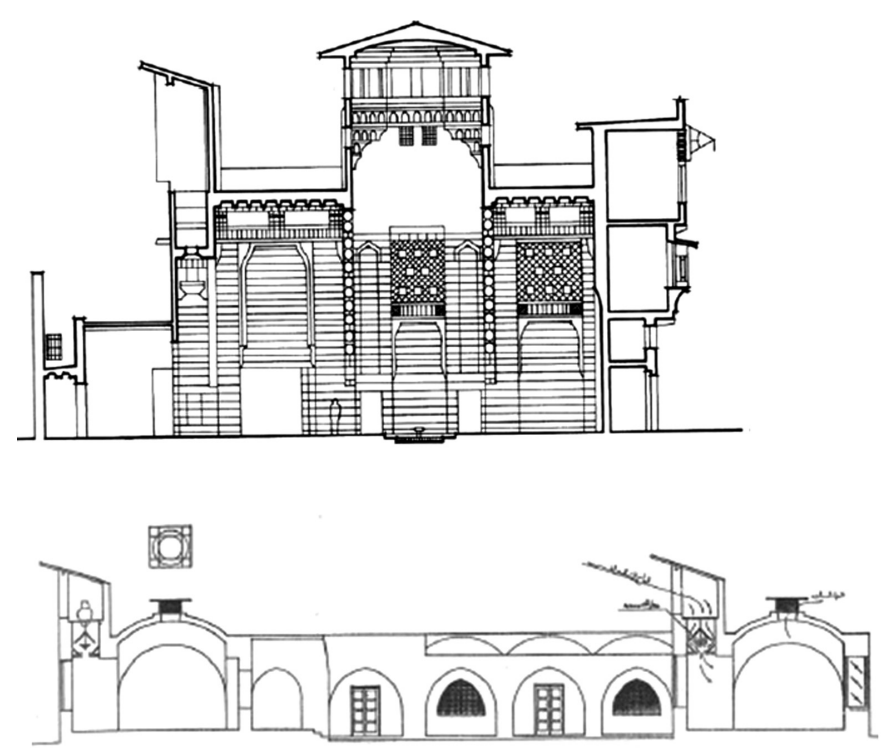
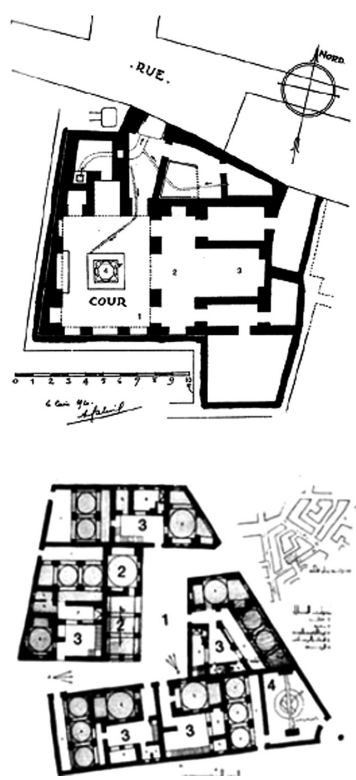

Figure 13: Old Cairo houses (above) were an inspiration design of public buildings (girls school) and houses in Gourna (below) [12, 19]. 


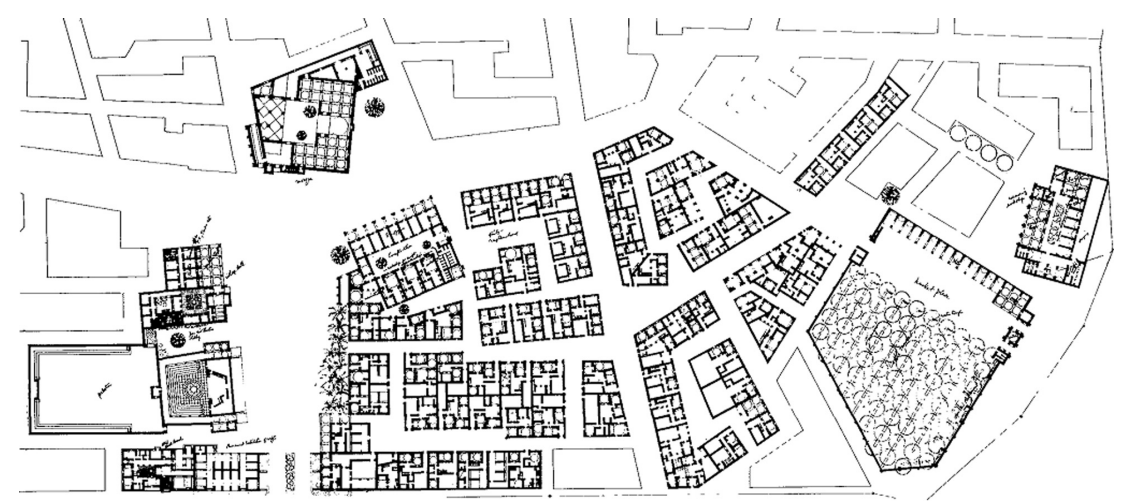

Figure 14: The New Gourna partially completed master plan, 1948 [5].
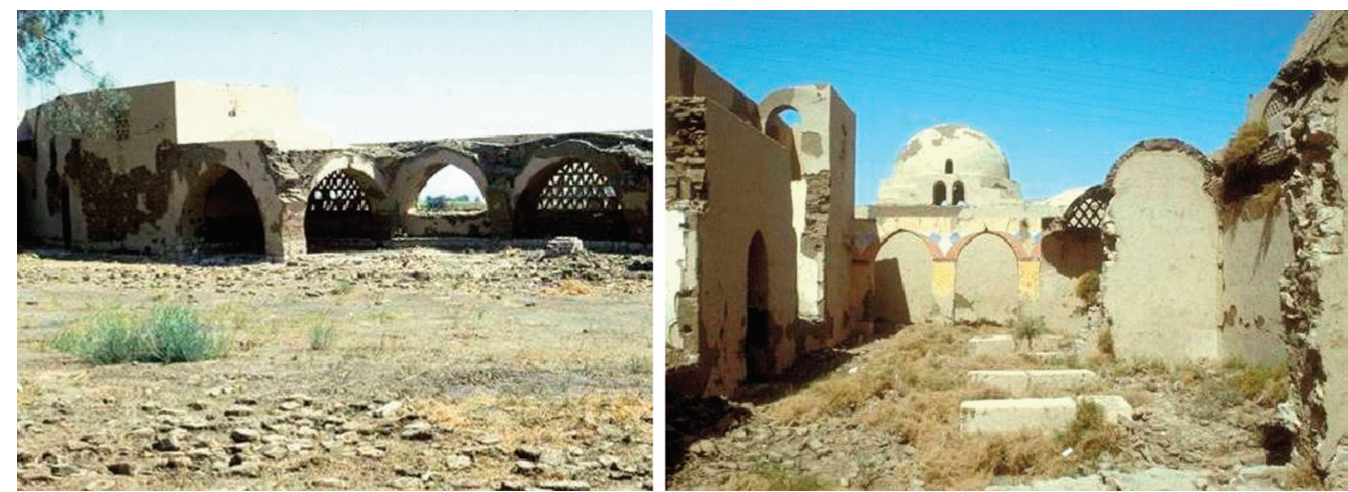

Figure 15: The New Gourna village turned into ruins [17].

\subsection{How sustainable was Fathy's New Gourna?}

Even with Fathy's noble goal of designing New Gourna in an environmentally, socially, and economically responsive manner, the Gournii, content with their living situation, resented the project and therefore, were reluctant to cooperate [5]. In order to justify the failure of the project Fathy characterized the Gournii as thieves and tomb robbers. This, according to Thiessen [14], not only provided a legitimate reason for the relocation of the villagers but also served as an external reason why his model village failed.

Serageldin [6] believes that the discourse about Fathy's New Gourna project now, as at the time of construction half a century ago, revolves around the extremely important question of how to create a culturally and environmentally valid (i.e. sustainable) architecture that is sensitive to ethnic and regional traditions without allowing subjective values and images to intervene in the design process. Criticism and discourse about the reasons for the failure of the project might cater for an answer to the question of sustainability of the project in its environmental, social, and economic dimensions. Most of the harsh criticism for Fathy's new Gourna project came on the social sustainability side. Nonetheless, other environmental and economic sustainability concerns have been raised.

On the environmental level, no doubt Fathy had exerted considerable effort in his attempt to produce what he believed to be more or less a 'sustainable' urban form and architecture for the new 
Gourna project. Nonetheless, much criticism was focused on the site selection where it has been claimed that the site for the New Gourna project was hardly ideal. Old Gourna had been located up on the hillside relatively distant from the Nile River in order to protect it from the annual floods and to preserve the most fertile land for farming. Although the new site was not in immediate danger from flooding but actually the site made its inhabitants much more susceptible to disease especially those caused by waterborne parasites such as bilharzias and malaria. This was a direct result of a rising water table accompanied by the lack of an annual flood to flush the system clean [14].

On the social level, some scholars such as Steele [15] believe that Fathy paid remarkable attention to the individual concerns and personalities of the inhabitants of a housing group. This, according to Steele, was certainly novel at this time, when European architects were each putting forward extremely regimented housing proposals. Steele believes that the occasional repetition of a house plan in New Gourna did not diminish the variety that was achieved especially in light of the difficulty that the architect had in obtaining information about his clients.

In contrast, Thiessen [14] is among other scholars who believe that the project had grown increasingly distant from its locale and alienated from its users. Thiessen argues that Fathy's New Gourna was a signifier of power structures, attitudes, and the ambitions of planners, bureaucrats, and Fathy's own class of urban land-owning elites. Therefore, Fathy's conception of an appropriate peasant aesthetic, as manifested in the New Gourna project, was based on an elite fantasy where peasants lived and looked as the Egyptian elite imagined they should. Thiessen adds that whether it was through modern blocks of concrete houses or pastoral mud brick villages, the Egyptian elite were utterly convinced that an aesthetic for living could affect social change and that the peasants would adopt the mentality evoked by their surroundings. As an evidence for his argument Thiessen mentioned that through the late 1930s and into the 1940s Fathy produced spectacular mud brick urban villas, rural estates houses for Cairo's elite in the same style he applied at New Gourna. Thiessen concluded that New Gourna project was based upon a totalizing social and aesthetic vision, which in practice totally disregarded all local considerations.

Edward Said, the famous Arab scholar, determined some points of criticism to Fathy's Gourna that in his claim harmed its credibility [15]. First is the 'exteriority' where the forms of domes and vaults, which predominate in massing of the village (Figs 10 and 11), may be argued to have been objectified and have been used superficially for scenic effect corresponding to the Orientalist style of using common figures of speech or narrative devices to represent a phenomenon under study. Second is the 'order knowledge', where the repetition of a fabricated mythology or set of stereotypes, rather than the use of an empirically tested system as an ontological claim to authenticity, has been interpreted in Fathy's selection of typologies of the qa' a, maqaad, and takhtaboosh that he employed in all residential designs (Fig. 13). All these typologies were extrapolated from the manzils or mansions of wealthy Cairene merchants of the twelfth through the eighteenth century in the medieval quarter of the city in which Fathy lived (Fig. 13). Third is 'didacticism'. Fathy constructed a building system that can be argued to conform to the Orientalist tendency to impose an order on specific representations to defend this ordering as being the product of learned systematic research to give it academic authority. The habit of presenting such an ordering of undifferentiated reality as a benefit to the culture for whom such ordering is undertaken certainly applies to all of Fathy's descriptions of his intentions for New Gourna.

It might be argued that another social concern associated with the physical elements of the designs of the housing units in New Gourna is their lack of flexibility and thus their inability to accommodate the changing needs of the inhabitants and hindering their incremental development. The evidence for that could be easily found in many alterations undertaken by the residents to make their houses much more responsive to their real distinctive and ongoing changing needs. This of course came on account of the aesthetic qualities emerging from the design of rigid items such as domes, vaults, and rigid thick walls (Fig. 16). 

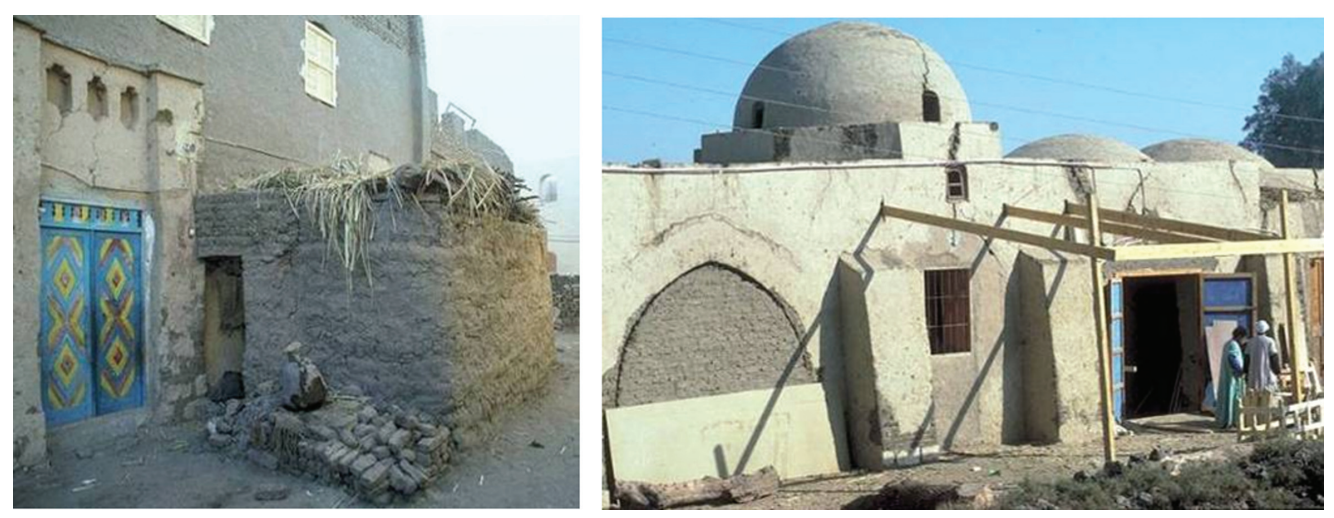

Figure 16: Adaptation by residents to accommodate their needs [17].

On the economic level, and beyond his confidence in the absolute economic value of teaching the villagers how to make mud-brick houses, Fathy's only attempt to provide for the village's economy was to teach a few of the children some arts and crafts that could be sold to tourists, yet even he admitted that these projects met with little success [14].

In a sudden, and actually disappointing, step Fathy proposed in 1970 to convert the remains of his New Gourna into a 'Touristic Village' with more craft shops and hotel rooms added to accommodate visitors. This proposal, which was fully designed but not built, contrasts sharply with the idealistic vision outlined in Fathy's book Architecture for the Poor and the fact that he could so easily contemplate such a conversion contrasts sharply with his own hesitation about his capacity for commercialism [15].

This analysis shows that most sustainability-related shortcomings in Fathy's New Gourna project came from the social and economic sides. The principal reason for that is the explicit absence of genuine participation of the Gournii on the different levels of the decision-making processes. Fathy [12] himself admitted that the masons and he himself had restored the creative relationship between designer and craftsman and thus brought together two members of the dispersed trinity. Meanwhile, the third member, the user, did not play a full part in New Gourna project. Fathy believed that this was not his fault, and he was sure that in any future project the three members will cooperate harmoniously and fruitfully as once they used to.

\section{SECOND VERSION OF NEW GOURNA: THE 'NEW AL TAREF' VILLAGE}

After many decades from its first attempt to move the residents from Gourna, the Egyptian government repeated the attempt on the same background of protecting Pharaonic monuments. The second version of the New Gourna, known officially as the 'New Al Taref', came significantly different from Fathy's New Gourna project. The work in this new village began in 1997 and finished in 2006, while transferring the Gournii to their new homes began on 15 August 2006. In order to force the residents to leave their houses in old Gourna and move to the new site, the government demolished most of these houses (Fig. 17) and left only 30 to be like an open museum for Gourna vernacular architecture and to be re-used as studios for artists from all over the world [8].

The new Al Taref occupies about 286 acres on the west bank of the Nile River (Fig. 1) and was intended to accommodate 3200 transferred families (12,000 inhabitants approximately) of the seven regions (nogoa) of old Gourna. The whole village was constructed by The National Service Projects Agency of The Egyptian Armed Forces with a total cost of around 170 million EL. The funding for the project construction was provided by different governmental ministries including the Ministry of Tourism, the Ministry of Culture, and the Ministry of Electricity and Energy [3]. 

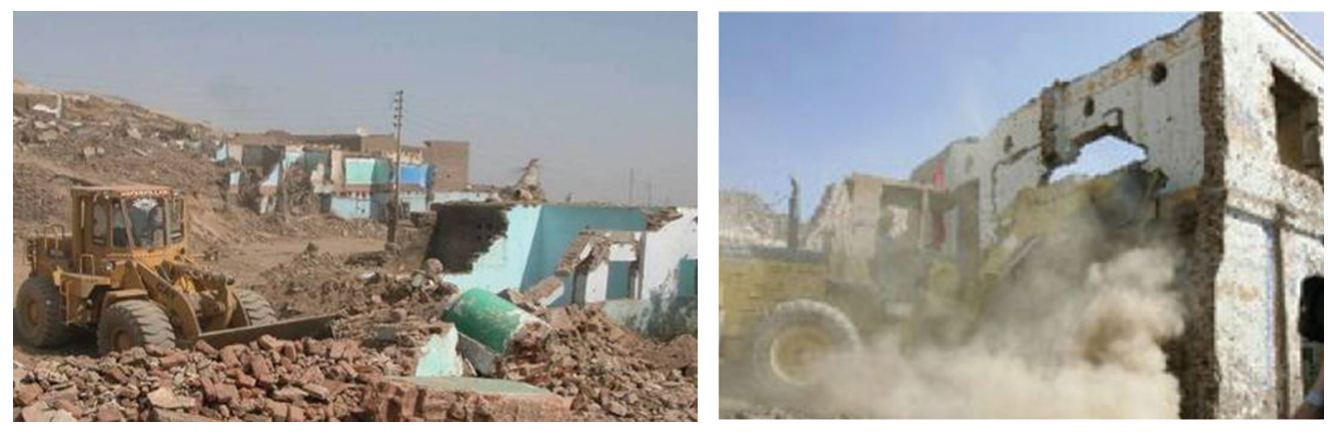

Figure 17: Destruction of Old Gourna in 2006 to force its residents to leave to the New Al Taref Village (the second version of New Gourna). Source: [10] and www.alarab.co.uk.
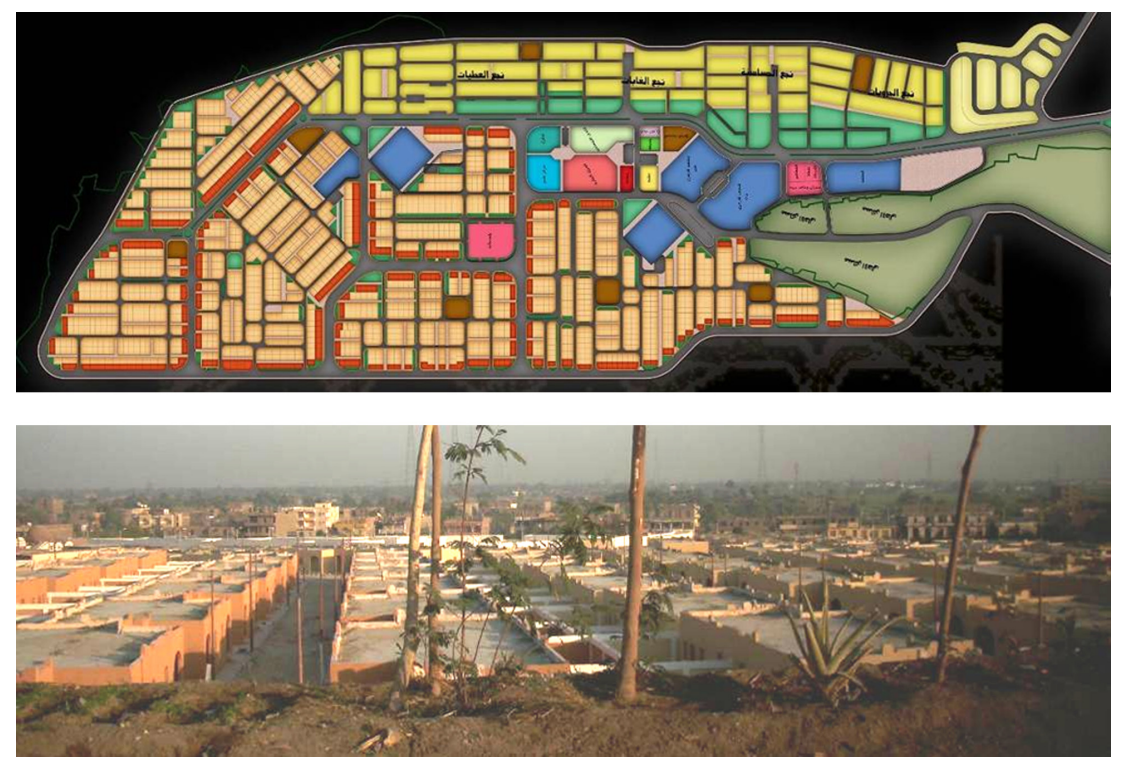

Figure 18: Al Taref, the layout of the village. Source: [10] and Authors.

\subsection{Urban and architecture development of the New Al Taref}

The layout of the New Al Taref followed the criteria of the design of conventional residential districts where mixed-use has been avoided with most of the services accumulating in one central area (Fig. 18). Similar to the case of Fathy's New Gourna, where the layout of the main streets separated the four quarters of the village allocated for the main four tribal groups of Old Gourna, in the layout of this version of the New Gourna each of the nogoa was allocated a district near to the central services area of the layout (Fig. 18).

Around 2000 typical turnkey one floor housing units, with an area of about 175 sq. m, were built to accommodate the transferred families of old Gourna. Only 80 sq. m out of this area is the built-up area while the rest of it is a used as a backyard. The houses were given to the transferred residents of Gourna for free with a permission to build another upper floor by themselves if they wished [9]. The typically designed houses have three bedrooms, a seating area, a kitchen, and a bathroom. Outside there is a small yard at the back. At the front, there is a porch-way and a little built-in seating area (mastaba) in 
front of the main bedroom, which has a door leading outside (Fig. 19). Among the total number of the built houses, about 100 smaller ones have been prepared for widows. In addition, 3000 serviced building plots were allocated for the better off 1500 families who are allowed to build four-story walk up residential blocks by themselves but according to typical pre-prepared design models sharing the same identical architectural style. The total area of each plot is about $200 \mathrm{sq}$. $\mathrm{m}$. and they were also given to the residents for free [9]. This option was also available for those of residents who do not want the built housing unit. In this case, they will be given two plots instead of the completed housing unit [20]. The distribution of the housing units and housing plots was undertaken by a special committee without any intervention from the local authority representative, the chairman of the Luxor City Council. The members of this committee were representing both the local authority and the residents [8].

The new village has been provided with functional and efficient infrastructure systems including asphalt paved roads, landscape, drinking water, electricity, and sanitation systems. It has been also linked to Luxor city via a new road. Concerning public services, the village has two K-12 schools, a youth center, a mosque, a police station, a clinic, and bakeries (Fig. 20) [9].
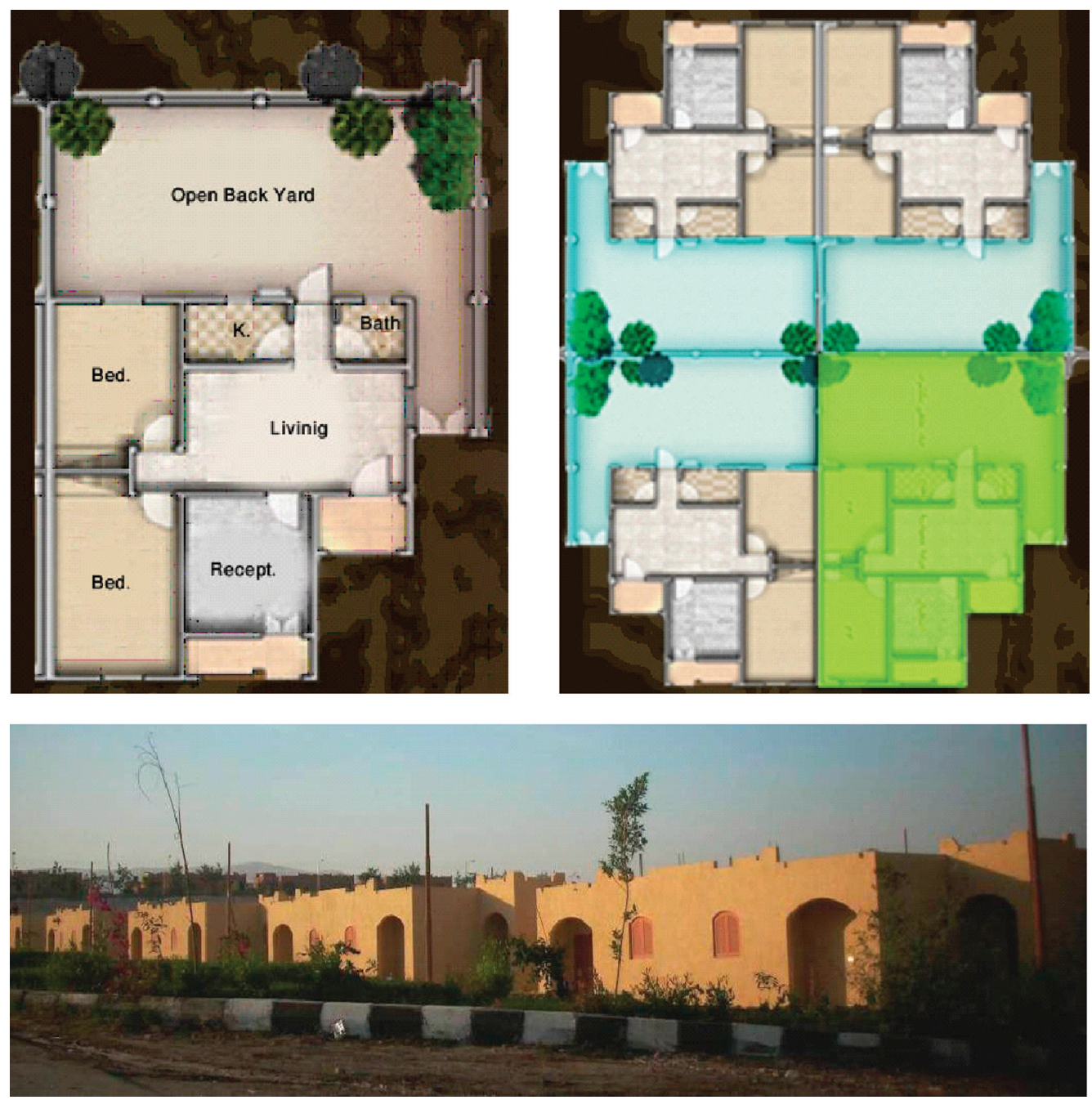

Figure 19: Al Taref, the typical houses. Source: [10] and Authors. 

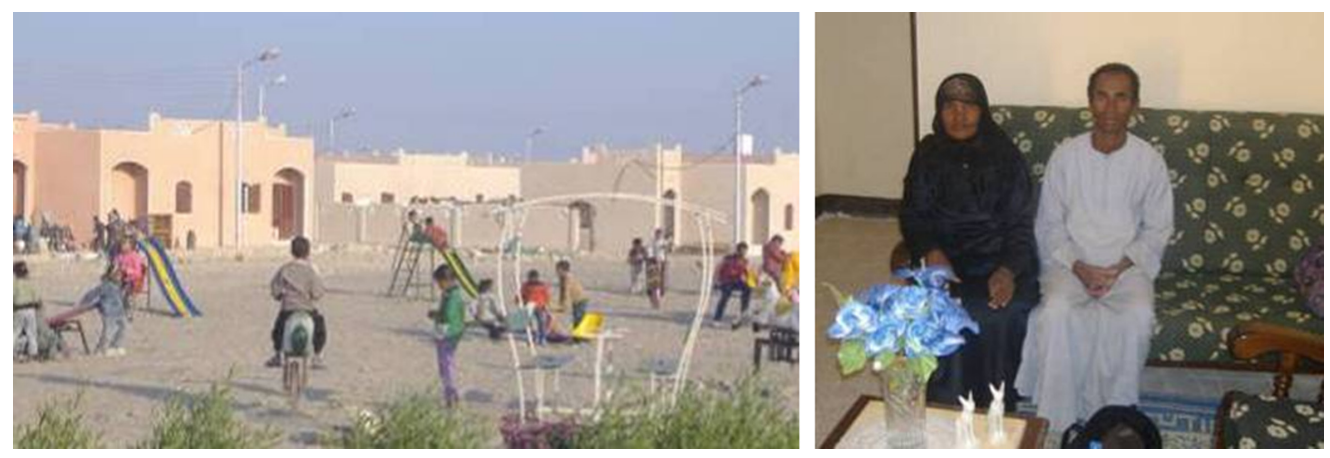

Figure 20: Playground for children in New Al Taref and the new living environment [21].
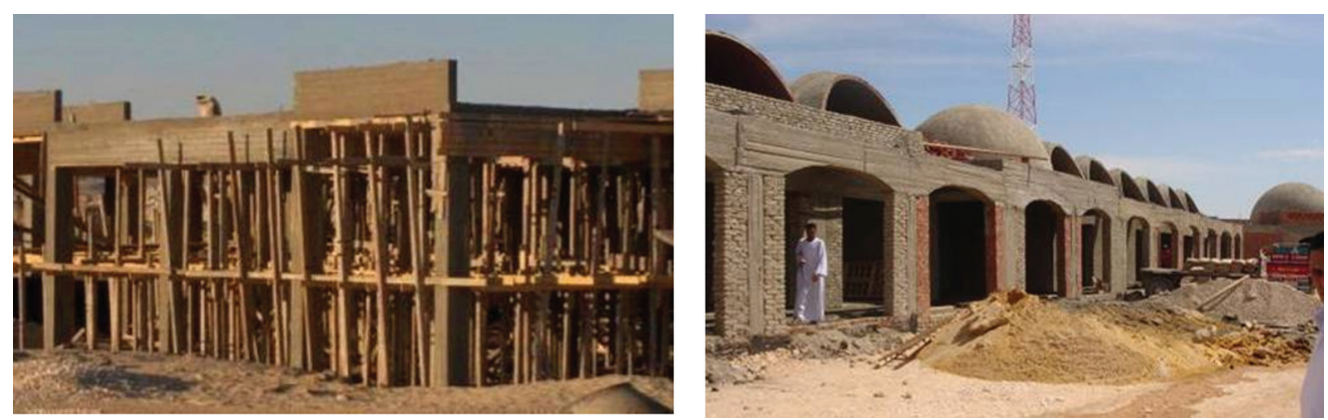

Figure 21: The local building materials have been replaced by conventional building materials from $\mathrm{RC}$ and Red Brick and were imported to the region and replaced [10].

\subsection{The 'New Al Taref' experience: a step forward towards sustainability or vice versa?}

In relation to sustainability, the criticism for New $\mathrm{Al}$ Taref project pivots around all of its three environmental, social, and economic domains. On the environmental level, the selected site is far away from the tourist destinations. This has made it extremely difficult for residents to commute to their workplaces without relying on mechanical means of transportation. This, besides avoiding mixeduse approach in the planning of the layout, is causing more consumption of fossil fuel leading to pollutants such as $\mathrm{CO}, \mathrm{CO}^{2}$ emissions, and other harmful gases. Another environmental problem is the irrigation of the vast green areas in the new village with clean water through trucks thus wasting water especially in the extremely hot climate of the region.

Absence of locality in the whole construction process represents one of the main environmental problems associated with this project. The adopted building materials are reinforced concrete and burnt red brick (Fig. 21) that can be found anywhere in Egypt regardless of their suitability for the specific climatic conditions of the region.

Also, in comparison to the local building materials used in old Gourna, the production of these materials necessitates much higher level of energy and they are, to a far extent, nonrecyclable.

On the other hand, the organization of the housing masses in this regimented manner has not achieved the proper orientation for each house. Thus, natural cross-ventilation and/or appropriate daylighting for a considerable number of houses have been compromised. Furthermore, no insulation materials have been provided for the external envelope of the buildings to help preventing heat 

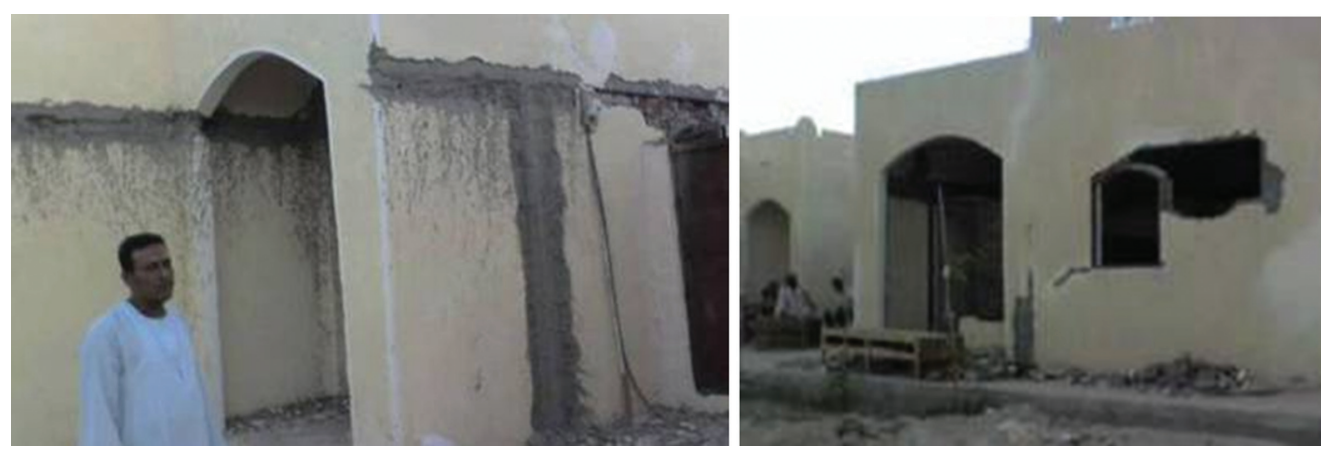

Figure 22: Cracks immediately appeared in some of the new houses in New Al Taref project. Source: www.youtube.com.

gain. Shading devises have also not been utilized over fenestrations to prevent direct solar heat gain. Only narrow streets helped in providing some shade. The inner courtyard, which used to be a climatic regulator in old Gourna, was transferred in the new designs to the back of the house, playing only a functional role (Fig. 19).

As an indicator of the irresponsiveness of the used building materials to the harsh climatic conditions, cracks immediately appeared in some of the new houses, especially between the RC beams and columns on the one hand and the red burnt bricks walls on the other hand (Fig. 22).

On the social level, the chairman of the Luxor City Council claimed that the social dimension has been considered in the planning of the new village. This, in his opinion, has been reflected in allocating a residential quarter in New $\mathrm{Al}$ Taref Village for each group of inhabitants from old Gourna to keep having their social relationships. Nonetheless, the social related problems of the design of the new village can be easily observed. Difference in social circumstances was not considered in the allocation process of the new houses that had followed rules that most of the residents could not understand. This is simply because all the areas of the housing units and plots are equal. Therefore, no matter how big the residents' old house was or how many family members they have, they are offered only one story, two bedroom houses that look like makeshift seaside chalets. As a result, many residents claimed that there was no equity in the allocation process of the houses and housing plots in the new village and thus they have not been fairly compensated.

Other residents believe that they have no identification with the new site of the New Al Taref. In an interview one of the villagers pointed out that it is not a question of compensation but of the fact that his home in old Gourna is the place where his great grandparents have lived and he believes that nobody has the right to force him out [22]. One of the Western archeologists who spent 17 years in Luxor mentioned that those people who live in Old Gourna are the main attraction for tourists with their distinguished artifacts and even their distinctive lifestyle [23].

Although the chairman of the Luxor City Council claimed that the area of the housing unit is thought to be appropriate to the transferred families [20], the residents themselves have a different opinion. Many of the transferred residents complained about the built-up area of the new houses. They believe that the 80 sq. $\mathrm{m}$. housing unit is too small for them, especially for those who have big families. One of the residents said that his family is composed of nine persons and they used to live in a house with an area of about 700 sq. m; therefore, he wonders how he can live with his big family in such a small house in the new village. Another resident said that his family is an extended one, which consists of sixteen persons, so they should have at least three houses but the government instead allocated them a 200 sq. m. serviced plot that needs at least 20,000 EL to be built and they do not have this amount of money [8]. 
As a result of the lack of an appropriate built-up area of the housing unit, many of the domestic activities are conducted now in the open space in front of the houses such as preparing bread for baking besides the appropriation of these spaces in traditional socialization among male or female residents (Fig. 23).

It might be claimed that the new village design reflects negligence and/or superficial dealing with vernacular art and architecture of the Gournii. Various alien architectural styles have been adopted. For example, the architectural style of the school building is 'Modern'; the police station is Pharonic; the hospital is Neo-Classic; and the houses are Nubian (Fig. 24). On the other hand, the central market seems to be superficially driven from Fathy's Gourna market with items such as the concrete vaults and domes only meant to give a pseudo-Gournii style (Fig. 25).
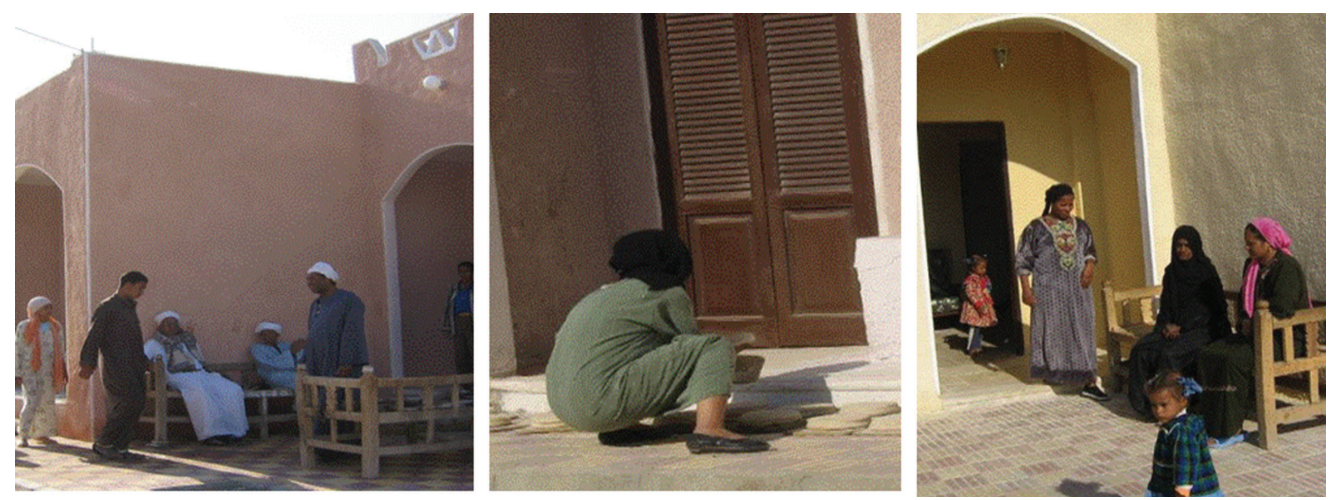

Figure 23: Appropriation of the open spaces in front of the new houses in New Al Taref [10].
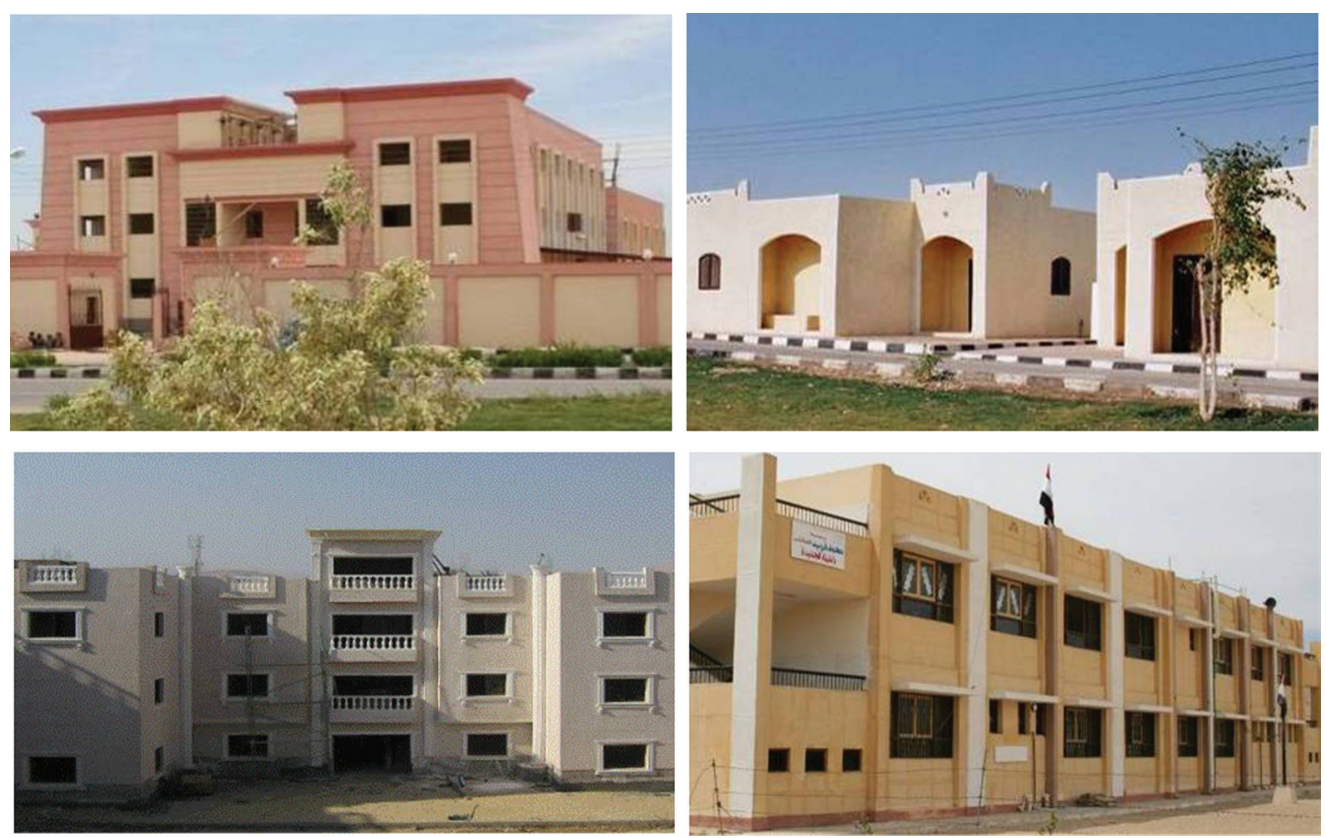

Figure 24: Different architectural styles for the buildings in New Al Taref Village [10]. 

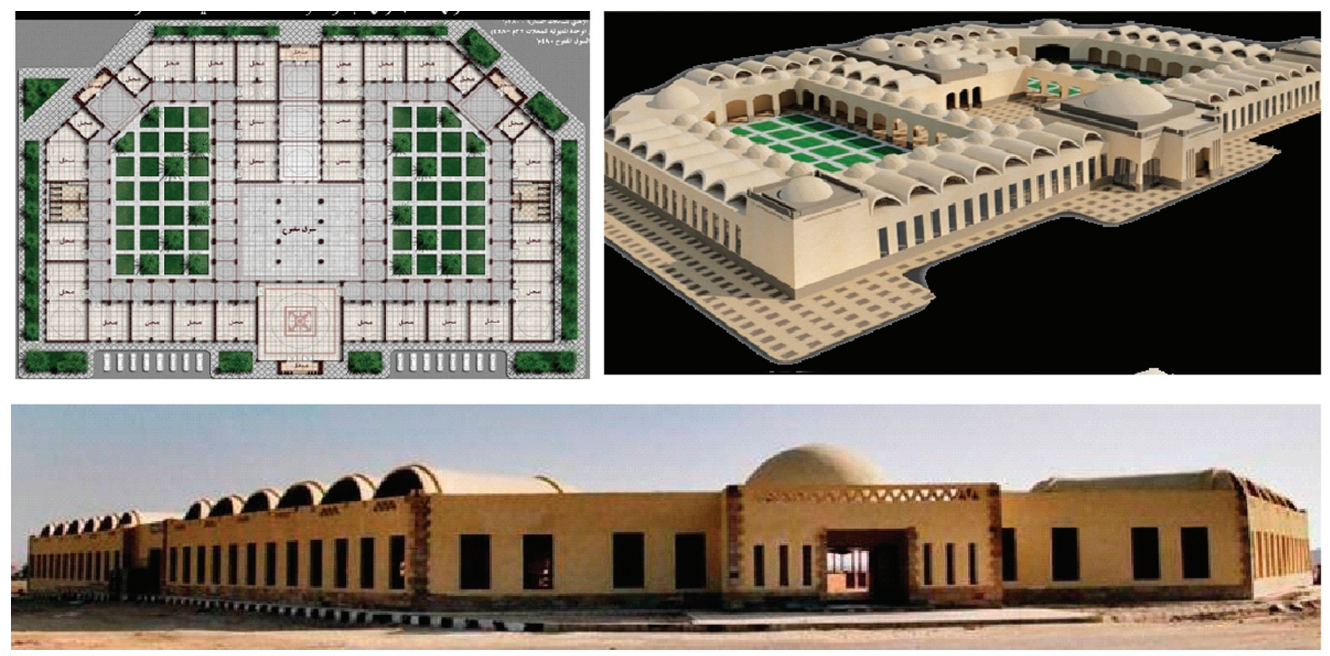

Figure 25: The pseudo-Fathy's design of the market in New Al Taref [10].

On the economic level, the New Al Taref is located approximately 3 kilometers away from old Gourna and from any tourist sites. Many of the residents who used to work in alabaster workshops cannot afford paying for pubic transportations and so they have to walk. One of the young residents commented that 'there are no foreigners there (in New Al Taref) and if there are no tourists so eventually there is no job'. Instead of the self-sustained community that used to be in old Gourna, the government through this project made the community totally dependent on it in providing all the needed amenities. It is obvious that everything is going to have to come from outside by the government including the furniture. Residents said they had been promised even electrical equipments such as washing machines, TVs, and fans, which they were yet to receive [23].

\section{DISCUSSION: TWO VERSIONS OF 'NEW GOURNA' AND SUSTAINABILITY}

The comparison of the two distinctive versions of the New Gourna experiences, Fathy's New Gourna and New Al Taref, based on whether they succeed to preserve and develop the sustainable vernacular architecture of old Gourna environmentally, socio-culturally, and economically, as analyzed earlier, will lead to the attainment of the main research objectives and shed light on the proper methods that ought to be adopted when dealing with urban regeneration and rehabilitation projects especially for the vernacular rural communities in Egypt.

On the environmental level, the modern and efficient infrastructure of the New Al Taref is helping in providing a healthier living environment for the people of Gourna. This, though demanded huge capital investments, but managed to treat an acute environmental problem that threatened the lives of Gourna residents in old Gourna through chronic diseases. Fathy [12] in his designs suggested some methods to overcome the problems associated with the absence of proper infrastructure in New Gourna such as hand water pumps and waterborne drainage but he himself admitted that these tools were not enough to end up with a healthy community.

Being away from the tourist destinations in the region, the chosen site for New Al Taref, as well as Fathy's New Gourna, necessitates the mechanical means of transportation needed to link workplaces with residential areas. This inevitably increases the wasteful consumption of fossil fuel and subsequently the $\mathrm{CO}^{2}$ emissions. 
Concerning site development, New Al Taref adopted a compacted but regimented layout. This helped, on the one hand, in producing shaded streets but on the other the arrangement of building masses in this way neglected the achievement of proper building orientation that helps in providing natural ventilation. Fathy's New Gourna layout adopted more flexible organization of masses to facilitate more natural ventilation and daylighting.

For climatic responsiveness house design, the inner court in the New Al Taref that used to serve the purpose of providing natural lighting and ventilation has been replaced by an outside rare courtyard used for only functional purposes. The efforts that Fathy exerted to study the environmental performance and the treatment of each individual building mass have been entirely neglected in the design of the buildings of New Al Taref where all the housing units came identical with no concern to the effect of the harsh environmental conditions of the regions.

The suitability of the used building materials in New Al Taref is also questionable from the environmental point of view. Fathy [12] mentioned that in Kom Ombo, a city in Upper Egypt, the concrete houses, similar to those of New Al Taref, built by the sugar company for its employees, proved to be too hot to live in during summer and too cold in winter. Therefore, the employees preferred to live in the mud houses of the peasants. The cracks that appeared in the newly built reinforced concrete and red burnt brick houses in New Al Taref is a good evidence for the unsuitability of these building materials in such a very hot climate. The domes and vaults that used to play a real role as climaticresponsive building elements have been superficially used in the market of Al Taref for mere superficial aesthetic purposes.

On the socio-cultural level, what happened in New Al Taref in comparison to Fathy's New Gourna has been based on professionals, rather than the elite, fantasy where peasants envisaged to live and look as the academic professional designers of the village imagined. Fathy mentioned that in a regular village plan like a gridiron, the houses would have been forced into a uniform design too [15]. This is what actually happened in the New $\mathrm{Al}$ Taref where boring ranks of identical dwellings, as Fathy described, were often considered to be all that the poor deserve [15]. This eventually harmed the vernacular housing environment of old Gourna and replaced it with a global one that can be easily found in many public housing projects in Egypt. In contrast, Fathy attempted to imitate and preserve the visual culture of the urban fabric of old Gourna through his irregular plan that supported variety and originality in the design and thus provided a constant visual interest.

Utilization of open spaces in old Gourna in a hierarchical order was another social force that Fathy attempted to keep in his design for New Gourna. In New Al Taref no such study for spaces was supplied for residents to allow them to socialize and practice many of their traditional activities as they used to do in the old Gourna.

Heath [1] maintains that in addition to broad patterns of influence, the vernacular may be prompted by the act of an individual as an agent of change. This individuality, which once distinguished the vernacular architecture of old Gourna and which Fathy tried to achieve even with little actual success, has been totally ignored with the adoption of the design for housing models that are very regimented and box-like leaving no room for change and amendment to satisfy the individual needs. People are not allowed to adapt or change anything in their houses as long as this might compromise the appearance of facades.

Fathy argued in his book Architecture for the Poor [12] that when the architect is faced with the job of designing a thousand houses at one time, rather than the dream for the thousand whom he must shelter, he designs one house and puts three zeros to its right, denying creativity to himself and humanity to man. As if he were a portraitist with a thousand commissions and painted only one picture and made nine hundred and ninety nine photocopies. This describes well the situation in the second version of New Gourna where only one housing model is repeated with no consideration for 
individual needs and preferences that once shaped the old Gourna. So, expression of change, one of the traits of vernacular architecture of old Gourna, has been practically lost. Heath [1] believes that vernacular architecture often points to an observable condition of dynamic cultural and environmental change; it speaks of transition rather than stasis. It marks a liminal period, a threshold of conscious change and accommodation expressed in the built form, whereby simultaneous identities result.

Fathy [12] admitted that in his own design he could not ignore all that the Gournii had done and erase every vestige of their own creativity. He was keen to incorporate not only the traditional construction process but more importantly the spirit of the Gournii, which he tried to bring out in his new designs. Fathy added that his search for local forms and his attempt to incorporate them in the New Gourna village was not prompted by his sentimental desire to keep some souvenir of the old village. Rather, the purpose was always to restore to the Gournii their heritage of vigorous locally inspired building tradition, involving the active cooperation of informed clients and skilled craftsmen. Despite Fathy's claim that he had done his best to preserve the authentic vernacular identity of Gourna in his New Gourna design, the architecture heritage of old Gourna was significantly affected in Fathy's designs where it was significantly replaced by architectural vocabularies from Nubian architecture and Old Arab cities. Fathy himself implemented the resultant style of New Gourna project frequently in several projects in different geographic locations for different social strata.

What happened in the second version of New Gourna (New Al Taref) is exactly what Fathy avoided in his design. Fathy [12] claimed that most architects when re-planning a village arrange the houses in straight, orderly streets, parallel to one another. He believed that this is easy, but dull because when these parallel streets consist of uniform, minimum-standard houses unrelieved by vegetation or other features, the effect is sordid and depressing. Additionally, in New Al Taref not only have the authentic architectural features of old Gourna been alienated but also the adopted architectural styles of the village buildings came as a collage of inharmonious architectural styles. Various adopted styles were used for the houses (Nubian), the police station (Pharaonic), the schools (modern), and the hospital (Neo-Classic) while the market imitated Fathy's New Gourna market. In Fathy's market design the vaults and domes came as appropriate techniques where people can build them by themselves using local materials. However, in New Al Taref vaults and domes are merely meant for superficial appearance and have been built using alien building materials and techniques imported to the region from outside.

On the economic level, the location of the village site has been essential in income generation through selling alabaster handicraft to tourists. For both versions of New Gourna site allocation was not appropriate economically as they were far away from tourist destinations that used to be close to the residents in old Gourna.

The mixed-use urban feature of Gourna helped people to generate their income by different means including having shops on the ground floors of their houses, renting rooms of their houses to tourists, raring poultry, and so on. Fathy faced little success when he tried to train the residents on traditional artifacts. As a result of the absence of a mixed-use planning approach in New Al Taref, people have been deprived the flexibility of generating income that they used to enjoy in their old vernacular community. While Fathy utilized cheap local building materials in his project, this was entirely and deliberately lost in New Al Taref. Besides the poor thermal performance of the reinforced concrete and burnt red brick, none of these materials are feasibly recyclable. For the cost of construction Fathy tried to train the residents on the Nubian construction methods to let them share in building their houses by themselves thus decreasing the building cost significantly. In New Al Taref professionals actually left no room for people to act in the construction process, which was completely undertaken by contractors who came from outside the community. 
In brief, in his design for New Gourna, Fathy attempted to, more or less, imitate the physical mass and space of old Gourna through the irregular crooked layout and various designs for houses, but wanted to do them by himself or with help from residents as builders not genuine partners as decision-makers. Fathy also used local building materials but with alien building technologies. The typologies of housing inner spaces were also historically imported as they were derived from traditional Arab architecture. In New Al Taref, no real effort has been exerted to learn from the vernacular environment of Gourna, rather it has been radically replaced by a city neighbourhood-like and pseudo-urban community similar to those found everywhere in Egypt. Both the building materials and construction methods were far from being local. The whole construction process has been totally undertaken by professional with relatively high cost.

Although the designers in both the experiences of New Gourna claimed that they took the needs of the Gournii into their consideration, they actually ended up with a total destruction of the process that produced the very sustainable vernacular architecture of Gourna. Therefore, it might be claimed here that the most rigorous problem that was the root of most of the subsequent ones is the deliberate alienation of the inhabitants from the planning-design-construction decision-making processes. Thus, it is argued that both attempts to build a New Gourna reveal how the top-down official processes might end up with a superficial mimic to the authentic vernacular architecture, as in the case of Fathy's Gourna, or even imposing a totally different built environment on the local community, as in the case of the New Al Taref. Even with Fathy's dream to take individual needs into consideration, the two cases share, to some extent, the negligence of the native residents as the main expert of vernacular architecture and imposing the architects' viewpoints on them. Most of the sustainability assets historically embedded in the Gourna vernacular architecture have been compromised and the vision of professionals and politicians eventually dominated the whole decision-making process. As a result of this attitude, people who used to historically produce their own sustainable living environment are now becoming extremely dependent on the government to do everything for them. Thus, it is expected that the New Al Taref project is going to end up in failure as its Fathy's predecessor project.

\section{CONCLUSION}

The research argues that the second version of New Gourna, namely New Al Taref, as well as the first version of it, of course with some major differences, has demolished the sustainable vernacular architecture of Gourna as it left no room for people to act. This sheds light on the fact that no real appropriate vision has been realized so far in dealing with the dichotomy of development on one hand and sustaining the environmental, socio-cultural, and economic dimensions of vernacular architecture on the other. Based on that, the research draws attention to the urgent need for an alternative approach when undertaking urban regeneration or rehabilitation projects in the regions that enjoy inherent sustainable vernacular architecture in order to sustain their social, cultural, economic, and environmental essence and not to sustain their architectural characteristics in a superficial and cosmetic manner. This proposed approach should provide a real atmosphere for people's actions and interactions without imposing office-prepared solutions on them. Instead, professionals and officials should help people find solutions for their own problems including the appropriate way to develop their skills in a way that matches the era of our time and, in the meantime, to preserve the values and traditions that would help them sustain their vernacular architecture, environmentally, socially, and economically.

\section{REFERENCES}

[1] Heath, W.K., Vernacular Architecture and Regional Design: Cultural Process and Environmental Response, Elsevier Ltd.: Oxford, 2009.

[2] GMP, Zero energy tower. Architecture Plus, (18), p. 40, 2008. 
[3] Godah, M., Luxor prepared for the President's visit. Al Akhbar, (17071), p. 3, 2007.

[4] Luxor, www.egypt.travel.

[5] Richards, J.M., Serageldin, I. \& Rastorfer, D., Hassan Fathy, Concept Media \& Architectural Press Ltd.: London, 1985.

[6] Serageldin, I., Hassan Fathy, Bibliotheca Alexandrina Press: Alexandria, 2007.

[7] Wikipedia, http://en.wikipedia.org/wiki/Kurna.

[8] Nasr, M., Rehabilitation of 3200 Families in New Taref, Watani, 22 April 2007, www.wataninet. com/article_ar.asp?ArticleID=10930.

[9] Ibrahim, A. \& Ghitah, H., The New Taref Village in Luxor: a practical exam for the desert village. Al Ahram, p. 28, 2006.

[10] Luxor Supreme Council, Current Status of City of Luxor Master Plan 2030, An Official Report, Luxor Supreme Council: Luxor, 2008.

[11] Stephens, R.D., People of Gourna, http://egypt.adventure.freeservers.com/photo15.html.

[12] Fathy, H., Architecture for the Poor: An Experiment in Rural Egypt, University Of Chicago Press: Chicago, 2000.

[13] Egyptos, Le village de Gourna, www.egyptos.net/egyptos/photos/Tombes-TombeauxVallee-des-nobles-Village-de-Gourna.

[14] Thiessen, M.N., Contested Representations and the Building of Modern Egypt: The Architecture of Hassan Fathy, Unpublished Master of Arts Thesis, Simon Fraser University: Ottawa, Canada, 2006.

[15] Steele, J., Orientalism and the Other: the Case Of Hassan Fathy, Unpublished PhD Dissertation, Faculty of the Graduate School, University of Southern California: Los Angeles, 2002.

[16] Steele, J., The Hassan Fathy Collection. A Catalogue of Visual Documents at the Aga Khan Award for Architecture, The Aga Khan Trust for Culture: Bern, Switzerland, 1989.

[17] Gourna, www.Archnet.net.

[18] Ibrahim, A., Arab Architects: Hassan Fathy, Center for Planning and Architecture Studies: Cairo, 1985.

[19] Fathy, H., Natural Energy and Vernacular Architecture: Principles and Examples with Reference to Hot Arid Climates, United Nations University and University of Chicago Press: Chicago, 1986.

[20] Alsa'ed Press, Alsaedpress faces Dr Samir Farag the Chairman of Luxor City, www. alsaedpress.com.

[21] Akshar, J., Gourna Updates, http://touregypt.net/teblog/luxornews/?p=405.

[22] Arabist, Gourna: Where the Dead Come First, http://arabist.net/hatshepsut/?p=24.

[23] Akshar, J., New Gourna, http://touregypt.net/teblog/luxornews/?p=357. 